\title{
An evaluation of the effect of grass silage and concentrate feed level on ewe and subsequent progeny performance and on potential concentrate sparing effect
}

T W J Keady, J P Hanrahan

Teagasc, Athenry, Co. Galway, Ireland

Email: tim.keady@teagasc.ie

Introduction Nutrition in late pregnancy influences lamb weight at birth and at weaning. Each $1 \mathrm{~kg}$ increase in lamb birth weight increases weaning weight by $3.2 \mathrm{~kg}$ to $3.4 \mathrm{~kg}$ (Keady and Hanrahan, 2009a,b). Previous studies (Keady and Hanrahan, 2009c, d) have shown that increasing silage feed value increases the weight of ewes at lambing and of their lambs at weaning. Keady and Hanrahan (2009c) reported that, when offered to pregnant ewes, high feed-value silage (FVS) supplemented with $5 \mathrm{~kg}$ concentrate produced lambs of similar birth and weaning weights as ewes offered medium FVS supplemented with either 15 or $25 \mathrm{~kg}$ concentrate. Furthermore Keady and Hanrahan (2009c) reported that when concentrate level was increased from 15 to $25 \mathrm{~kg} /$ ewe in late pregnancy silage feed value did not affect lamb birth or weaning weights. The aim of the present study was to quantify the production responses of prolific ewes when offered diets containing either medium or high FVS supplemented with a range of concentrates in late preganacy. The effect of silage feed value on potential concentrate sparing effects was also calculated.

Materials and methods High (H) and medium (M) FVS's were ensiled precision chopped on 12 May and 14 June respectively treated with a bacterial inoculant, following a $24 \mathrm{~h}$ wilting period. The $\mathrm{H}$ silage was supplemented with either 5,15 or $25 \mathrm{~kg}$ concentrate whilst the M silage was supplemented with either $15,25,35$ or $45 \mathrm{~kg}$ concentrate during late pregnancy. The 7 treatments were offered to 112 ewes (Belclare x S. Blackface, Charmoise x S. Blackface) balanced for breed and age, and were allocated at random. The ewes were housed on slatted pens in groups of 5 and offered the silages ad libitum from 8 December until lambing in early March. Ewes rearing singles and twins were grazed at pasture and received no concentrate supplementation. Ewes rearing triplets received $0.5 \mathrm{~kg}$ concentrate daily for 5 weeks post lambing and their lambs had access to $300 \mathrm{~g}$ concentrate/head daily until weaning at 14 weeks of age. The data were analysed using Proc GLM for ewe traits, and Proc MIXED for lamb traits with ewe as a random term. Orthogonal contrasts were used to partition the effect of concentrate level into linear and quadratic components within each silage type.

Results The mean dry matter (DM) and metabolisable energy concentrations and DM digestibility for the H and M FVS's were 257 and $248 \mathrm{~g} / \mathrm{kg}, 11.4$ and $10.5 \mathrm{MJ} / \mathrm{kg} \mathrm{DM}$ and 740 and $660 \mathrm{~g} / \mathrm{kg}$, respectively. The effects of silage feed value and concentrate level on animal performance are presented in Table 1. Increasing concentrate feed level with the medium FVS linearly increased ewe condition and weight post lambing and lamb birth weight. Increasing concentrate level with the high FVS tended $(\mathrm{P}=0.06)$ to increase ewe condition post lambing. Ewes offered the high FVS had significantly higher condition and weight post lambing. Concentrate level offered with the high FVS did not alter ewe live weight post lambing or lamb birth weight. Whilst there was no significant interaction between silage feed value and concentrate level at the 15 and $25 \mathrm{~kg}$ feed levels, regression analysis, using individual animal data, suggested different relationships for lamb birth weight and concentrate level for each silage feed value as follows:

High FVS: $\quad$ Lamb birth weight $(\mathrm{kg})=4.74+0.015($ s.e.0.0136) $\mathrm{x}$

Medium FVS: $\quad$ Lamb birth weight $(\mathrm{kg})=4.54+0.019$ (s.e. 0.0088$) \mathrm{x}$

$$
\left(\mathrm{P}<0.05, \mathrm{R}^{2}=0.07\right)
$$

where $\mathrm{x}=$ concentrate feed level in late pregnancy $(\mathrm{kg})$. Consequently ewes offered the high FVS supplemented with 5,15 and $25 \mathrm{~kg}$ concentrate produced lambs of similar birthweight as the medium FVS supplemented with 14,22 and $30 \mathrm{~kg}$ respectively.

Table 1 Effect of grass silage feed value on concentrate feed level on animal performance

\begin{tabular}{|c|c|c|c|c|c|c|c|c|c|c|c|c|}
\hline \multirow[b]{3}{*}{ Conc $(\mathrm{kg})$} & & \multirow{2}{*}{\multicolumn{3}{|c|}{$\begin{array}{l}\text { High feed values } \\
\text { silage }(\mathrm{H})\end{array}$}} & \multirow{2}{*}{\multicolumn{4}{|c|}{$\begin{array}{l}\text { Medium feed value } \\
\text { silage (M) } \\
\end{array}$}} & \multirow[b]{3}{*}{ se } & \multicolumn{3}{|c|}{ Contrasts } \\
\hline & & & & & & & & & & \multirow{2}{*}{$\begin{array}{l}\mathrm{H} \mathrm{v} \\
\mathrm{M}\end{array}$} & \multicolumn{2}{|c|}{ Conc level linear } \\
\hline & & 5 & 15 & 25 & 15 & 25 & 35 & 45 & & & $\mathrm{H}$ & $\mathrm{M}$ \\
\hline \multirow[t]{2}{*}{ Post lambing } & -condition & 3.43 & 3.65 & 3.80 & 3.10 & 3.30 & 3.52 & 3.80 & 0.139 & $* * *$ & $\mathrm{P}=0.06$ & $* * *$ \\
\hline & -weight & 68.8 & 69.3 & 72.0 & 65.3 & 66.3 & 66.7 & 72.3 & 1.95 & $*$ & NS & $*$ \\
\hline \multicolumn{2}{|c|}{ Lambweight (kg)-birth } & 4.8 & 5.0 & 5.1 & 4.7 & 5.2 & 5.4 & 5.3 & 0.21 & NS & NS & $*$ \\
\hline & -weaning & 30.7 & 31.3 & 32.2 & 31.0 & 31.6 & 30.2 & 33.0 & 0.85 & NS & NS & NS \\
\hline \multicolumn{2}{|c|}{ Gain-birth-weaning (g/d) } & 267 & 272 & 281 & 271 & 275 & 258 & 288 & 7.8 & NS & NS & NS \\
\hline
\end{tabular}

Conclusions Increasing silage feed value and concentrate feed level increased ewe condition at lambing. In terms of lamb birth weight the concentrate sparing effect of the high FVS supplemented either 5,15 and $25 \mathrm{~kg}$ concentrate was 9,7 and 5 respectively.

\section{References}

Keady, T.W.J. and Hanrahan, J.P. 2009a. Animal 3, 143-151.

Keady, T.W.J. and Hanrahan, J.P. 2009b. Animal 3, 879-890.

Keady, T.W.J. and Hanrahan, J.P. 2009c. XV International Silage Conference. 133-134.

Keady, T.W.J. and Hanrahan, J.P. 2009d. Proceedings of the British Society of Animal Science, 70. 